\title{
A Case of Metastatic Renal Cell Carcinoma to Thyroid Gland Mimicking as Anaplastic Thyroid Carcinoma
}

\author{
Sooyeon Jo, Hyung Gyun Na, Chang Hoon Bae ${ }^{\mathbb{D}}$, and Yoon Seok Choi $\mathbb{E}$ \\ Department of Otorhinolaryngology-Head and Neck Surgery, College of Medicine, Yeungnam University, Daegu, Korea
}

갑상선 미분화암으로 오인된 갑상선으로 전이된 신세포암 1예

조수연 · 나형균 · 배창훈 · 최윤석

영남대학교 의과대학 이비인후-두경부외과학교실

\author{
Received June 9, 2020 \\ Revised August 7,2020 \\ Accepted September 9, 2020 \\ Address for correspondence \\ Yoon Seok Choi, MD, PhD \\ Department of Otorhinolaryngology- \\ Head and Neck Surgery, \\ College of Medicine, \\ Yeungnam University, \\ 170 Hyeonchung-ro, Nam-gu, \\ Daegu 42415, Korea \\ Tel +82-53-620-3785 \\ Fax $+82-53-628-7884$ \\ E-mail choiys@ynu.ac.kr
}

Metastatic cancers to the thyroid gland are rare, while the kidney is the most common primary site for metastatic cancers, occupying $42 \%$. Metastatic renal cell carcinoma (RCC) to the thyroid gland usually has no specific symptoms or signs, and no characteristic imaging findings. And metastatic RCC takes a long time to occur after curative treatment. Since RCC rarely metastasizes only to the thyroid gland without the metastasis of other organs, it is difficult to distinguish it from thyroid nodules or cancers with a relatively high prevalence. Unlike metastases from the breast or lung, metastatic RCC to the thyroid gland is difficult to diagnose by a fine needle aspiration biopsy, which is usually confirmed by immunohistochemical analysis after surgery. Therefore, it is difficult to establish a treatment strategy before surgery. Recently, we experienced a rare case of metastatic RCC to the thyroid gland mimicking as anaplastic thyroid carcinoma because of its aggressive clinical course.

Korean J Otorhinolaryngol-Head Neck Surg 2021;64(10):755-9

Keywords Metastasis; Renal cell carcinoma; Thyroid gland.

\section{서 론}

갑상선에 발생하는 암은 대부분 원발성암으로, 다른 장기 의 암이 갑상선에 전이되어 발생하는 갑상선 전이암은 전체 갑상선암의 $0.1 \sim 6 \%$ 정도를 차지하는 것으로 알려져 있다. ${ }^{1,2)}$ 갑상선 전이암은 주로 신세포암, 폐암, 유방암에서 기원되며, 그 중 신세포암의 전이가 $42 \%$ 로 가장 흔하다. ${ }^{2)}$ 그러나, 신세 포암의 다른 장기로의 전이가 동반되지 않고 갑상선에만 단 독으로 발생하는 경우는 신세포암 갑상선 전이의 $25 \%$ 를 차 지한다. ${ }^{3}$

신세포암의 갑상선 전이의 경우 무통성 종괴로 발견되는 경우가 대부분이며, 영상학적 검사에서 특징적 소견을 보이

This is an Open Access article distributed under the terms of the Creative Commons Attribution Non-Commercial License (https://creativecommons.org/licenses/by-nc/4.0) which permits unrestricted non-commercial use, distribution, and reproduction in any medium, provided the original work is properly cited.
지 않고, 원발 질환에 대한 치료 후 평균적으로 8 9년이 지 나서 발생하는 경우가 많아 진단이 어려운 경우가 많다. ${ }^{3-5)}$ 또한 폐암이나 유방암에서 기원한 갑상선 전이암과 다르게 수술 전 세침흡인검사에서 진단되는 경우가 드물어 치료전 략을 결정하기 어려운 경우가 많다. ${ }^{1,46-12)}$ 저자들은 최근 빠르 게 자라는 전경부 종물 소견과 종물의 기관지 침범으로 인한 급성 호흡곤란으로 응급실을 방문한 환자에서 응급 윤상갑 상막절개술(cricothyroidotomy)을 시행하였고, 이후 시행한 동결절편 조직검사에서 미분화 갑상선암 의심되어 갑상선 전 절제술 및 좌측 선택적 경부림프절 절제술 및 중심구역림프 절 절제술을 시행한 후 최종적으로 전이성 신세포암으로 진 단된 환자 1 예를 경험하였기에 문헌 고찰과 함께 보고하는 바 이다. 본 연구는 환자 증례 보고로 영남대학교 연구윤리심의 위원회로부터 심사면제 받아 진행되었다. 


\section{증 례}

79세 남자 환자가 점차 커지는 전경부 종물과 호흡곤란을 주소로 응급실을 내원하였다. 과거력상 8년 전 신세포암을 진 단받고 우측 신장 전적출술을 받은 병력이 있으며, 내원 1년 전부터 당뇨병을 진단받고 투약 중이었다. 가족력상 특이사 항은 없었다. 전경부 종물은 약 한 달 전 발견되어 점점 커지 는 양상으로, 내원 2주 전 타 병원에서 세침흡인 세포검사를 시행하였으나, 명확한 조직학적 진단을 얻지 못한 상태였으 며, 경과 관찰 중 종물이 빠르게 커지며, 호흡곤란이 발생하 여 본원 응급실로 전원되었다.

이학적 소견상 좌측 전경부 하부에 중심선을 넘어가는 약 $8 \times 4 \mathrm{~cm}$ 크기의 경한 통증을 동반한 단단한 종괴가 촉진되 었으며, 후두내시경 검사상 좌측 성대마비 소견과 함께 상부 기관에 기도 내강으로 돌출되어 기관 내경의 $80 \%$ 를 채우고
있는 종물이 관찰되었다(Fig. 1A). 경부 전산화단층촬영상 좌측 갑상선 엽에 $7.0 \times 5.5 \times 7.5 \mathrm{~cm}$ 크기의 경계가 불분명하 고 불균등한 조영 증강을 보이는 종물이 기관 후방을 통해 기관 내로 침범되어 있음이 확인되었다(Fig. $1 \mathrm{~B}$ and C). 환자 는 응급실에서 검사 중 호흡곤란 증상이 더욱 심해지고, 산 소의 공급하에서도 산소포화도가 떨어져, 응급기관절개술을 시도하였으나 전경부를 막고 있는 종물의 크기가 너무 크고 출혈량이 많아 시야확보가 어려워 기관절개술을 실패하였으 며, 윤상갑상막절개술로 전환하여 $6 \mathrm{french}$ 크기의 기관 내 튜브를 이용하여 종물이 막고 있는 좁아진 부분을 통과하여 기도를 확보하고 전신 마취로 전환하여 동결절편 조직검사를 시행하였다. 검사상 미분화 갑상선암이 의심된다는 소견을 얻었으며, 일차적으로 갑상선 전적출술을 시행하였고, 술전 영상학적 검사에서 명확한 림프절의 전이가 관찰되지 않았으 나, 공격적인 임상양상과 수술 중 시행한 동결절편검사 결과
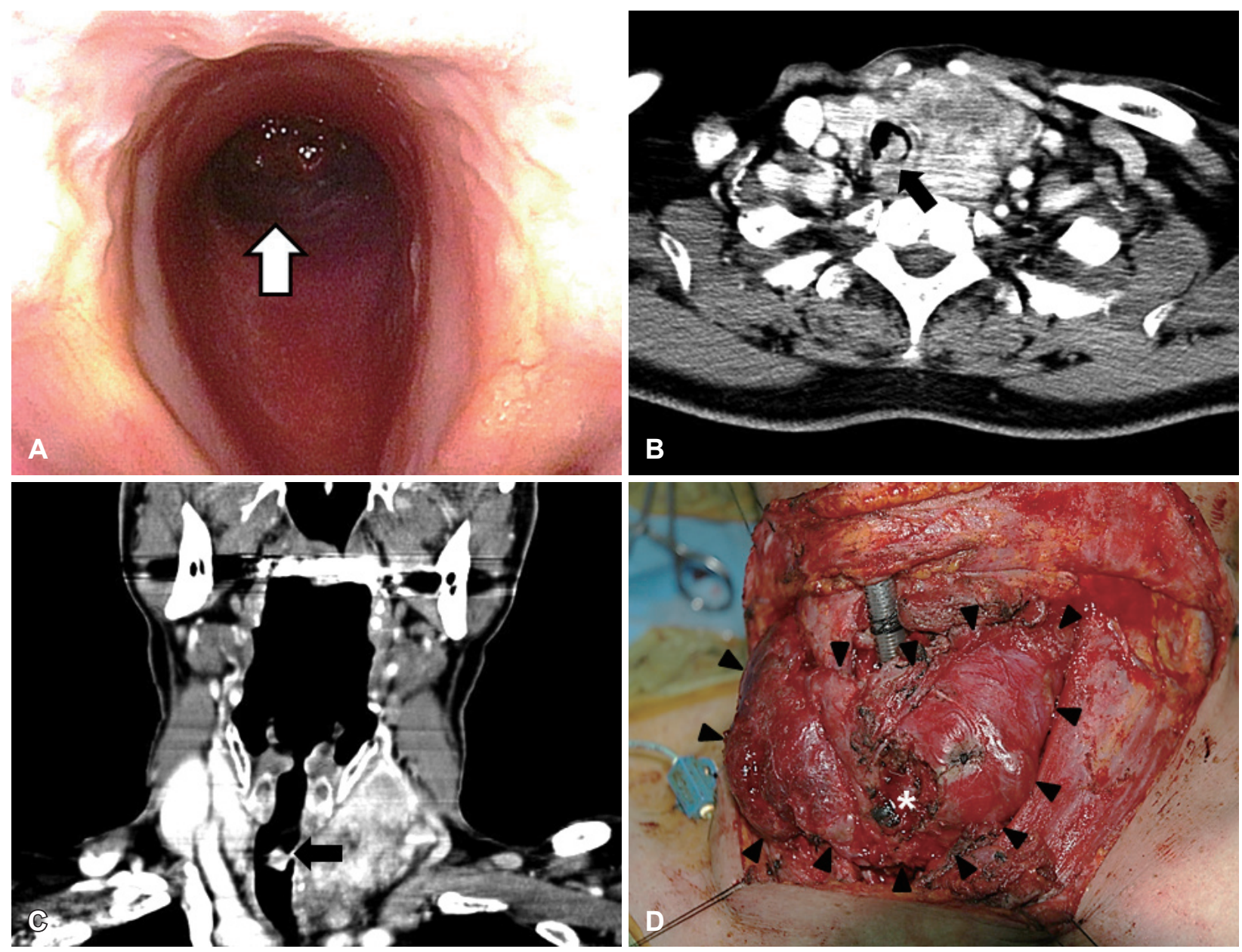

Fig. 1. Preoperative physical and image findings and intraoperative gross findings. Preoperative laryngoscopic finding showed that reddish lobulating mass (arrow) invaded the trachea and blocked most of the lumen of trachea (A). Axial \& coronal views of contrast enhanced neck CT scan showed that about $7.0 \times 5.5 \times 7.5 \mathrm{~cm}$ sized ill-defined enhanced lesion was originated from left lobe of thyroid gland and had invaded the trachea (arrows). However, definite lymph node enlargement was not noted (B, $C$ ). Intraoperative finding showed that about $7 \times 6 \mathrm{~cm}$ sized easy bleeding huge mass (arrowheads) infiltrated to thyroid gland and trachea. Some tissue was obtained for a frozen biopsy during surgery (asterisk) (D). 
등을 고려하여 예방적으로 좌측 선택적 경부림프절 절제술 (level II-IV)과 중심구역림프절 절제술(level VI)을 함께 시 행하여 종물과 함께 일괴로 제거하였다. 그리고 종양이 침범 된 기관지를 기관지 내강으로 침범한 종물과 함께 제거하고 윤상갑상막을 통해 삽입된 기관 내 튜브를 이동하여 기도를 유지하였으며, 개방된 윤상갑상막은 봉합하였다. 제거된 기관 지 절단면에 잔여 종양조직이 없음을 동결절편검사 통해 확 인한 후 기관지 절단면의 점막과 피부를 3-0 nylon을 이용 하여 봉합하여 기관지 측면에 기관절개창을 만들고 상처부 위를 봉합하고 수술을 종료하였다. 수술소견상 종물은 전경 부를 모두 덮을 정도로 매우 컸으며, 쉽게 출혈하는 경향을 보였다(Fig. 1D). 종물은 기관의 좌후방을 통해 기관 내강으 로 침투한 상태로, 기관지 연골고리 2 6번까지 침습되어 있 었으나, 식도로의 침범은 관찰되지 않았다. 수술 중 시행한 추가 조직검사를 통해 절제면의 안전경계를 확인한 후 수술 을 종료하였다.
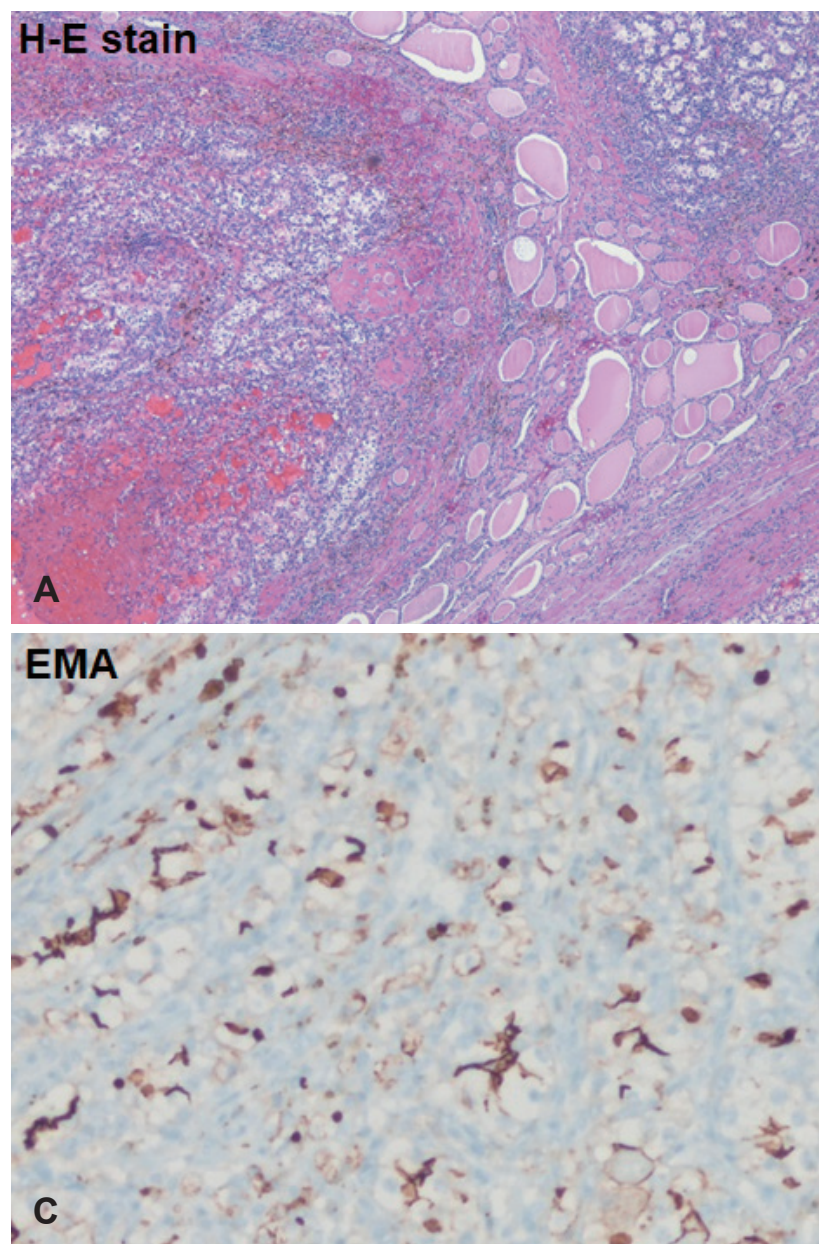

Fig. 2. Histopathologic and immunohistochemical findings of specimen. H\&E stain showed that nested cells with clear cytoplasm were infiltrating the thyroid tissue (original magnification $\times 40)(A)$. Immunohistochemical analysis showed that the tumor cells were strong positive for CD10 (B) and EMA (C), but negative for thyroglobulin (D) (original magnification $\times 200$ ). H\&E: hematoxylin and eosin, CD10: cluster of differentiation 10, EMA: epithelial membrane antigen.

수술 후 시행한 병리조직검사에서 확인된 종물의 크기는 $7.0 \times 5.5 \mathrm{~cm}$ 였으며, 경부 절제술로 얻어진 29개의 림프절에서 림프절 침범소견은 관찰되지 않았다. 조직학적 소견에서 투명 세포암에 적합한 소견을 관찰할 수 있었으며(Fig. 2A), 면역 화학적 염색 검사에서도 cluster of differentiation 10(CD10), epithelial membrane antigen(EMA)에 양성 및 갑상선 글로 불린에 음성소견을 보여 갑상선으로 전이된 신세포암으로 최 종 진단하였다(Fig. 2B-D). 환자는 수술 후 시행한 양전자단 층촬영(PET-CT)을 통해 잔여병변과 다른 장기에 추가적 전 이가 없음이 확인되었고, 환자의 나이, 전신상태, 병의 예후 등을 고려하여 보조치료는 시행하지 않았다. 환자는 수술 1년 까지 재발 소견이 관찰되지 않아 좌측 성대마비에 대한 치료 로 반영구적인 물질을 이용한 성대주입술을 시행하였으며, 기관절개창을 피부피판을 이용하여 닫아주었다. 환자는 4년 이 지난 현재 특이 합병증 및 재발 소견 없이 외래 경과 관찰 중이다.

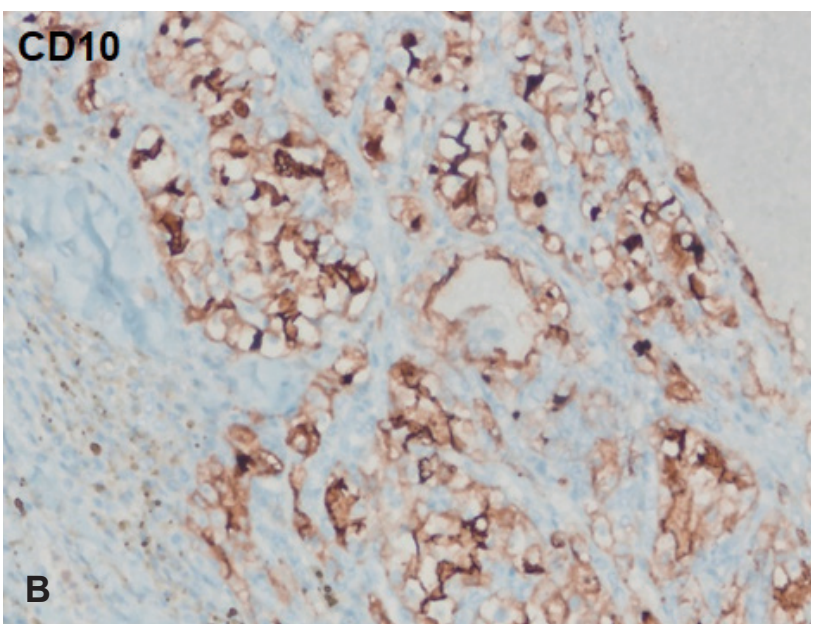

\section{Thyroglobulin}

D

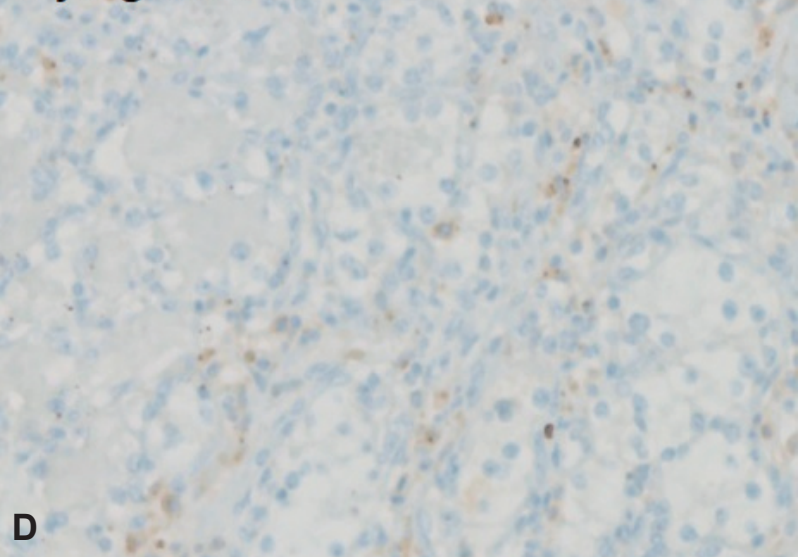




\section{고 찰}

신세포암은 성인에서 발생하는 악성 종양의 $3 \%$ 를 차지하 며, 약 $40 \%$ 에서 다른 장기로의 전이가 발생하는 것으로 알 려져 있다. 전이 빈도는 폐, 임파선, 빼, 간의 순서를 보이며, $0.07 \%$ 의 빈도로 매우 드물게 갑상선에 전이되기도 한다. ${ }^{3,4}$ 더욱이 본 증례처럼 갑상선에만 단독 전이를 보이는 경우는 더욱 드물다. ${ }^{3)}$ 갑상선은 악성 종양의 전이가 드문 장기로, 전 이암은 전체 갑상선암의 $0.1 \sim 6 \%$ 가량을 차지한다. ${ }^{1,2)}$ 이는 혈 류량이나 혈류 속도가 높은 갑상선 내 혈관의 성격으로 인해 종양 세포가 정착하기가 힘들고, 갑상선 내 혈관이 고요오드 상태에 있어 종양세포의 발육을 억제하기 때문이라고 해석 되고 있다. ${ }^{13)}$

갑상선으로 전이된 신세포암의 경우 무증상의 종괴로 발견 되는 경우가 대부분이며, 삼킴장애, 목소리 변화 등의 증상을 보일 수도 있다. ${ }^{3,6-12)}$ 그러나, 드물지만 본 증례와 같이 기관을 침범하여 급성 호흡곤란을 유발하는 경우도 있다. ${ }^{14)}$ 또한, 전 이성 신세포암은 원발부위의 근치치료 후 수개월에서 수십년 까지 다양한 기간에 걸쳐 발생하며, 전이암 발생까지 평균기 간이 8.7 9.6년으로 매우 길다. ${ }^{3-5)}$ 이렇듯 전이성 신세포암은 다양한 임상증상을 나타내며, 전이암이 발생하는 시점에 대 한 예측이 어렵고, 비전형적인 전이양상을 보이는 경우가 많 아 병력청취를 통한 신세포암의 치료 과거력에 대한 확인은 전이성 신세포암을 진단하는데 매우 중요한 부분이다. ${ }^{3)}$ 그러 나 신세포암의 갑상선 전이의 경우, 갑상선 결절과 갑상선 암 의 상대적으로 높은 유병율로 인해 병력청취상 환자의 신세 포암에 대한 병력을 인지하였다 하더라도 신세포암의 갑상선 전이를 임상적으로 진단하기는 쉽지않다. Song 등의 보고에 서도 알 수 있듯이 신세포암의 갑상선 전이의 경우 저에코, 명확하지 않은 종양의 경계, 높은 혈류량 등의 비특이적인 초음파 소견을 보여 원발성 갑상선암이나 갑상선결절과 구별 되는 특징적인 소견이 없으며, 세침흡인검사를 통해서는 조 직학적으로 진단하기가 쉽지 않아 중심부바늘생검 또는 진단 적 수술을 통해 진단되는 경우가 흔하다.,5) 본 증례의 경우 에서도 환자는 내원 2주 전 타 병원에서 세침흡인검사를 시 행하였으나, 암을 의심할 수 있는 조직학적 근거를 확인하지 못하였으며, 심한 호흡곤란으로 인해 수술 전 추가적인 조직 검사를 고려하지 못하였고, 응급 윤상갑상막절개술 이후에 시행한 동결절편 조직검사에서 조차 전이성 신세포암을 의심 할 만한 소견을 얻지 못하였으며, 수술 후 시행한 면역조직검 사소견을 통해 최종 진단을 할 수 있었다.

저자들은 최근 20년 간 국내에 보고된 신세포암의 갑상선 전이 8예를 확인해 본 결과 수술 전 시행한 세침흡인검사에
서 전이성 신세포암이 진단되었던 예는 없었으며, ${ }^{6-12)}$ Song 등 ${ }^{4}$ 의 연구에서도 세침흡입검사를 시행한 8 명 중 1 명에서만 전이성 종양의 존재를 의심하였다. 이러한 점을 고려할 때 다 른 장기의 암으로 치료받은 병력이 있는 환자에게서 발견된 갑상선 종물에 시행하는 수술 전 세침흡인검사의 임상적 유 용성에 대해 다시 고찰해 볼 필요가 있다고 판단된다. 특히 고령의 환자, 다른 장기에도 전이암이 의심되는 병변이 동반 되어 있거나 진행이 빠른 갑상선 종물의 경우 침습적이더라 도 중심부바늘생검을 초기에 적극적으로 고려하여 적절한 치료계획을 확립하는 것이 필요하다고 생각된다.

갑상선으로 전이된 신세포암의 조직학적 진단소견은 본 증 례와 같이 조직학적으로 세포질이 투명하고 풍부하며, 크고 둥근 과다염색핵을 가지며, 핵소체가 잘보이는 특징이 있다. 면역화학염색 검사에서는 $\mathrm{CD} 10, \mathrm{EMA}$ 염색에 양성소견을 보 이고, 갑상글로불린 염색상에서는 음성소견을 보인다. ${ }^{3-12)}$ 갑 상선에 발생한 전이성 신세포암의 경우 다른 장기의 전이가 동반되지 않을 경우 갑상선 전절제술 또는 아전절제술이 주 로 시행되고 있으며,") 대체적으로 예후가 좋은 것으로 알려져 있다. ${ }^{3,6-12)}$ 본 증례의 경우는 보고된 다른 증례들과 다르게 임상적으로 매우 침습적이고 공격적인 양상을 보였다. 또한 수술 중 동결절편 조직검사에서도 병리학적 진단을 얻지 못 하여 미분화갑상선암의 가능성을 고려한 갑상선 전적출술과 선택적 경부림프절 절제술 및 중심구역림프절 절제술을 시행 하였으며, 최종 조직검사에서 신세포암의 갑상선 전이가 발 견된 진단이 어려웠던 드문 증례였다.

본 증례를 통해 세침흡입검사에서 명확히 진단되지 않은 갑상선 종괴를 가진 환자의 경우 드물지만 전이암의 가능성 은 항상 고려하여야 하며, 세심한 병력청취와 중심부바늘생 검과 같은 적극적인 조직검사 조기에 시행하여 원발성 갑상 선암과 감별이 필요함을 확인할 수 있었다. 또한 갑상선에 단 독으로 전이된 신세포암의 경우 임상적으로 공격적인 양상을 보이더라도 적절한 수술적 치료가 이루어질 경우 성공적인 치료결과를 얻을 수 있음을 확인할 수 있었다.

\section{Acknowledgments}

This research was supported by Basic Science Research Program through the National Research Foundation of Korea (NRF) funded by the Ministry of Science, ICT \& Future Planning (NRF-2016 R1C1B1011395).

\section{Author Contribution}

Conceptualization: Yoon Seok Choi. Data curation: Sooyeon Jo. Funding acquisition: Yoon Seok Choi. Investigation: Hyung Gyun Na. Project administration: Chang Hoon Bae. Resources: Yoon Seok Choi. Supervision: Chang Hoon Bae. Visualization: Hyung Gyun Na. Writing — original draft: Sooyeon Jo. Writing—review \& editing: Yoon Seok Choi. 


\section{ORCIDs}

Yoon Seok Choi

https://orcid.org/0000-0002-0616-7122

Chang Hoon Bae

\section{REFERENCES}

1) Chung AY, Tran TB, Brumund KT, Weisman RA, Bouvet M. Metastases to the thyroid: A review of the literature from the last decade. Thyroid 2012;22(3):258-68.

2) Czech JM, Lichtor TR, Carney JA, van Heerden JA. Neoplasms metastatic to the thyroid gland. Surg Gynecol Obstet 1982;155(4): 503-5.

3) Khaddour K, Marernych N, Ward WL, Liu J, Pappa T. Characteristics of clear cell renal cell carcinoma metastases to the thyroid gland: A systematic review. World J Clin Cases 2019;7(21):3474-85.

4) Song OK, Koo JS, Kwak JY, Moon HJ, Yoon JH, Kim EK. Metastatic renal cell carcinoma in the thyroid gland: Ultrasonographic features and the diagnostic role of core needle biopsy. Ultrasonography 2017;36(3):252-9.

5) Kobayashi K, Hirokawa M, Yabuta T, Fukushima M, Masuoka H, Higashiyama T, et al. Metastatic carcinoma to the thyroid gland from renal cell carcinoma: Role of ultrasonography in preoperative diagnosis. Thyroid Res 2015;8:4.

6) Kim DJ, Jang LC, Choi JW, Park JW. Metastatic clear cell renal cell carcinoma to the thyroid gland. Korean J Endocr Surg 2012;12(3):

$185-7$.

7) Lee JG, Yang Y, Kim KS, Hyun CL, Lee JS, Koh G, et al. A case of metastatic renal cell carcinoma to thyroid gland. Chonnam Med J 2011;47(2):130-3.

8) Park SY, Chung YS, Choe JH, Kang KH, Han W, Noh DY, et al. Metastatic renal cell carcinoma to the thyroid gland. Korean J Endocr Surg 2006;6(1):39-41.

9) Cheon KI, Lee KW, Mok JO, Kim YJ, Park HK, Kim CH, et al. A case of papillary thyroid carcinoma combined with metastatic renal cell carcinoma in the thyroid. J Korean Soc Endocrinol 2006;21(1): 85-9.

10) Jung HS, Park YJ, Chung HS, Chang MS, Jin TH, Choi CS, et al. A case of renal cell carcinoma with thyroid metastasis. J Korean Soc Endocrinol 2003;18(3):318-24.

11) Lee JH, Lee JH, Kim IS, Jung KY. Two cases of renal cell carcinoma metastatic to the thyroid gland. Korean J Otolaryngol 2000;43(9): 1012-5.

12) Kim KS, Park WC, Kim J. A case report of metastatic renal cell carcinoma to thyroid. J Korean Surg Soc 1997;53(6):911-4.

13) Linton RR, Barney JD, Moorman HD, Lerman J. Metastatic hypernephroma of the thyroid gland. Surg Gynecol Obstet 1946; 83:493-8.

14) Rosen IB, Walfish PG, Bain J, Bedard YC. Secondary malignancy of the thyroid gland and its management. Ann Surg Oncol 1995; 2(3):252-6. 